\title{
Correlation of Oxygen Consumption and Patient Day with Invasive Mechanical Ventilation in a Hospital in Sao Paulo during Covid-19 Pandemic
}

\author{
Kaio Jia Bin ${ }^{* 1}$, Luana Alcantara Machado ${ }^{2}$, Nivaldo Fracacio Junior ${ }^{3}$, Francis Mironescu Tomazini ${ }^{4}$, \\ Paula Cristina Souto de Camargo ${ }^{5}$, Rosemeire Keiko Hangai ${ }^{6}$, Marcelo Camarotto ${ }^{7}$, Clarice Tanaka $^{8}$, \\ Antonio José Rodrigues Pereira ${ }^{9}$,
}

${ }^{1}$ Advanced Study Program in Hospital Administration and Health Systems, Hospital das Clínicas of the University of São Paulo School of Medicine, São Paulo/SP, Brazil; kaio.bin@hc.fm.usp.br; ORCID 0000-0002-3767-6288

${ }^{2}$ Multiprofessional residency in integrated health service management, Hospital das Clínicas of the University of São Paulo School of Medicine, São Paulo/SP, Brazil; luana.alcantara@hc.fm.usp.br; ORCID 0000-0003-2367-8829

${ }^{3}$ Advanced Study Program in Hospital Administration and Health Systems, Hospital das Clínicas of the University of São Paulo School of Medicine, São Paulo/SP, Brazil; nivaldo.fracacio@ @c.fm.usp.br; ORCID 0000-0003-0188-4031

${ }^{4}$ Department of Information Technology, Hospital das Clínicas of the University of São Paulo School of Medicine, São Paulo/SP, Brazil; francis.mtomazini@hc.fm.usp.br; ORCID 0000-0003-4862-2020

${ }^{5}$ Advanced Study Program in Hospital Administration and Health Systems, Hospital das Clínicas of the University of São Paulo School of Medicine, São Paulo/SP, Brazil; paula.camargo@hc.fm.usp.br; ORCID 0000-0001-6094-0895

${ }^{6}$ Advanced Study Program in Hospital Administration and Health Systems, Hospital das Clínicas of the University of São Paulo School of Medicine, São Paulo/SP, Brazil; rosemeire.hangai@ @c.fm.usp.br; ORCID 0000-0001-6645-1443 ${ }^{7}$ Department of Infrastructure and Logistics, Hospital das Clínicas of the University of São Paulo School of Medicine, São Paulo/SP, Brazil; marcelo.camarotto@hc.fm.usp.br; ORCID 0000-0002-3568-708X

${ }^{8}$ Department of Physical Therapy, University of Sao Paulo, São Paulo/SP, Brazil; clarice.tanaka@hc.fm.usp.br; ORCID 0000-0003-3900-5944

${ }^{9}$ Superintendence, Hospital das Clínicas of the University of São Paulo School of Medicine, São Paulo/SP, Brazil; antonio.pereira@hc.fm.usp.br; ORCID 0000-0002-8287-323X

Received 28 October 2021;

Accepted 12 November 2021;

Published 17 November 2021

\begin{abstract}
Background: The new coronavirus led the world into the pandemic known as COVID-19. Still, without any effective treatment, oxygen therapy is the most used treatment for patients. Without proper management of this medicinal gas, lives can be lost for lack of it. $\underline{\text { Aim: }}$ Find an indicator of a strong correlation with oxygen consumption. Methods: A single-center retrospective study, that evaluated the oxygen consumption billing data and patient-day indicator of Central Institute of HCFMUSP between 2019 and 2020. Results: A total of 380,245 patient days were analyzed. A strong correlation was identified between oxygen consumption and patient day with invasive mechanical ventilation (0.92). An average of $41.6( \pm 7.8)$ cubic meters per patient day with invasive mechanical ventilation was found. Conclusion: There is a strong correlation between oxygen consumption in cubic meters and patient days with invasive mechanical ventilation at the Central Institute of HCFMUSP. The average values of consumption per patient day can help in planning oxygen management in other hospitals.
\end{abstract}

Keywords: pandemic, oxygen consumption, public health, indicators, healthcare, invasive mechanical ventilation

\section{Introduction}

The sudden surge of severe acute respiratory syndrome coronavirus (SARS-CoV-2), caused by a novel RNA coronavirus named
COVID-19 that prompted the World Health Organization (WHO) to declare a pandemic, named COVID-19, on March 11, 2020, ${ }^{[1]}$ has affected the health management of countries around the world $^{[2]}$. 
Still without an effective treatment, since the beginning of the pandemic, the use of oxygen has been the most used therapy to treat patients ${ }^{[3,4]}$, and sustainable access to oxygen has been a challenge in low- and middle-income countries ${ }^{[5]}$.

In these countries, hospitals are running out of oxygen, which makes the management of this supply essential for the healthcare of patients affected by COVID-19, where its lack can mean loss of life ${ }^{[6,7]}$.

Despite this importance, there is little data on the consumption of this material in hospitals, which could be used for planning and action in times of health crisis.

To fill this knowledge gap, the authors carried out a survey of oxygen consumption at the Central Institute of Hospital das Clínicas of the University of São Paulo School of Medicine (HCFMUSP) and correlated it with one of the most common indicators of hospital management, the patient day.

\section{Objective}

This study aims to seek a correlation between oxygen consumption and the patient day and look for an index that can be used for planning the use of oxygen by hospitals.

\section{Methods}

\section{Study Type}

This is a single-center retrospective study.

\section{Study Setting}

The study was carried out using Oxygen consumption billing data and the Patient-Day indicator of the Central Institute of HCFMUSP.

\section{Population and Sample}

A survey of oxygen consumption billing and amount regarding patient-days was conducted in the Central Institute of HCFMUSP between the periods January 2019 to December 2020.
A total of 380,245 patient-day, all anonymous, were found. For each patient-day was checked the use of invasive mechanical ventilation was by medical order from the electronic medical record (EMR).

\section{Data Collect and Analysis}

The data was extracted in Excel version 2010 Microsoft Inc ${ }^{\circledR}$ from the Billing System and EMR.

Excel's Pivot Table was used for calculating the mean, percentages, standard deviation e correlation.

\section{Variables}

Oxygen consumption is taken from the billing system in cubic meters by month.

Patient day and patient day with invasive mechanical ventilation by medical order is taken directly from the EMR and grouped by corresponding month.

A rate of invasive mechanical ventilation (RIMV) was obtained by dividing the patient day with invasive mechanical ventilation by the total patient day of the corresponding month.

Oxygen consumption per patient day with invasive mechanical ventilation was obtained by dividing the total oxygen consumed in cubed meter by the total patient day with invasive mechanical ventilation of the corresponding month.

\section{Results}

Patient-Day and Invasive Mechanical Ventilation

As shown in Table 1, in 2019, the rate of invasive mechanical ventilation (RIMV) inpatient days ranged between $9 \%$ to $12 \%$, as well the first quarters of 2020 , ranging between $12 \%$ to $14 \%$. As soon as the COVID-19 breakout in Sao Paulo, the RIMV increased to $41 \%$ in April, peaking at $48 \%$ in the months June and July, with a gradual decrease down to $16 \%$ in December of 2020.

Table 1: Patient day, a patient day with the use of invasive mechanical ventilation and rate of use of invasive mechanical ventilation along 2019 to 2020

\begin{tabular}{|c|c|c|c|c|}
\hline Year & Month & Patient Day & Patient Day with IMV & RIMV \\
\hline \multirow[t]{12}{*}{2019} & January & 17.899 & 2.045 & $11 \%$ \\
\hline & February & 16.940 & 1.706 & $10 \%$ \\
\hline & March & 17.990 & 1.658 & $9 \%$ \\
\hline & April & 17.969 & 1.935 & $11 \%$ \\
\hline & May & 18.593 & 2.036 & $11 \%$ \\
\hline & June & 17.531 & 1.764 & $10 \%$ \\
\hline & July & 18.634 & 1.914 & $10 \%$ \\
\hline & August & 18.695 & 2.003 & $11 \%$ \\
\hline & September & 17.865 & 1.838 & $10 \%$ \\
\hline & October & 17.552 & 1.760 & $10 \%$ \\
\hline & November & 16.848 & 1.574 & $9 \%$ \\
\hline & December & 16.731 & 1.993 & $12 \%$ \\
\hline \multirow[t]{10}{*}{2020} & January & 18.247 & 2.114 & $12 \%$ \\
\hline & February & 16.371 & 1.821 & $11 \%$ \\
\hline & March & 15.398 & 2.083 & $14 \%$ \\
\hline & April & 9.556 & 3.962 & $41 \%$ \\
\hline & May & 15.603 & 6.738 & $43 \%$ \\
\hline & June & 15.124 & 7.202 & $48 \%$ \\
\hline & July & 10.353 & 4.923 & $48 \%$ \\
\hline & August & 8.312 & 3.001 & $36 \%$ \\
\hline & September & 12.345 & 2.515 & $20 \%$ \\
\hline & October & 15.110 & 2.111 & $14 \%$ \\
\hline
\end{tabular}




\begin{tabular}{|l|l|l|l|l|}
\hline & November & 15.297 & 2.105 & $14 \%$ \\
\hline & December & 15.282 & 2.413 & $16 \%$ \\
\hline
\end{tabular}

$I M V=$ invasive mechanical ventilation

RIMV = Rate of invasive mechanical ventilation

\section{Oxygen Consumption}

As shown in Table 2, the oxygen consumption ranged from 65 thousand cubic meters to 80 thousand cubic meters in 2019 , and increased along the months of 2020, peaking at 240 thousand cubic meters in June of 2020 and ending 2020 at 142 thousand cubic meters in December.

Table 2: Oxygen Consumption, Patient Day, and Patient Day with invasive mechanical ventilation along 2019 to 2020 by month.

\begin{tabular}{|c|c|c|c|c|}
\hline Year & Month & Oxygen Consumption in a cubic meter & Patient Day & Patient Day with IMV \\
\hline \multirow[t]{12}{*}{2019} & January & 76.924 & 17.899 & 2.045 \\
\hline & February & 73.428 & 16.940 & 1.706 \\
\hline & March & 69.314 & 17.990 & 1.658 \\
\hline & April & 69.726 & 17.969 & 1.935 \\
\hline & May & 80.010 & 18.593 & 2.036 \\
\hline & June & 70.343 & 17.531 & 1.764 \\
\hline & July & 67.874 & 18.634 & 1.914 \\
\hline & August & 79.392 & 18.695 & 2.003 \\
\hline & September & 66.949 & 17.865 & 1.838 \\
\hline & October & 75.793 & 17.552 & 1.760 \\
\hline & November & 65.715 & 16.848 & 1.574 \\
\hline & December & 75.382 & 16.731 & 1.993 \\
\hline \multirow[t]{12}{*}{2020} & January & 86.590 & 18.247 & 2.114 \\
\hline & February & 72.191 & 16.371 & 1.821 \\
\hline & March & 90.292 & 15.398 & 2.083 \\
\hline & April & 123.301 & 9.556 & 3.962 \\
\hline & May & 205.441 & 15.603 & 6.738 \\
\hline & June & 240.107 & 15.124 & 7.202 \\
\hline & July & 169.121 & 10.353 & 4.923 \\
\hline & August & 159.667 & 8.312 & 3.001 \\
\hline & September & 131.975 & 12.345 & 2.515 \\
\hline & October & 111.619 & 15.110 & 2.111 \\
\hline & November & 117.389 & 15.297 & 2.105 \\
\hline & December & 142.604 & 15.282 & 2.413 \\
\hline
\end{tabular}

$I M V=$ invasive mechanical ventilation

Applying the correlation test for the variable oxygen consumption was obtained a result of -0.60 when matching with the variable patient day, and 0.92 when matching with the variable patient day with invasive mechanical ventilation Indicating that the variables oxygen consumption and patient day with invasive mechanical ventilation have a strong positive linear correlation (Table 3).

Table 3: Correlation of Oxygen Consumption with Patient Day, and Correlation of Oxygen Consumption with Patient Day with invasive mechanical ventilation.

\begin{tabular}{|l|l|}
\hline Variables & Correlation (R) \\
\hline Oxygen Consumption and Patient Day & -0.60 \\
\hline Oxygen Consumption and Patient Day with IMV & 0.92 \\
\hline
\end{tabular}

$I M V=$ invasive mechanical ventilation

Due to the strong positive linear correlation, a patient day with invasive mechanical ventilation was used to obtain the index oxygen consumption per patient day.

As shown in Table 4, the consumption ranged from 35.5 to 43.1 cubic meters per patient day in 2019. And in 2020, ranging from 30.5 to 43.3 cubic meters per patient day until July, with an increase in the last five months, ranging from 52.5 to 59.1 cubic meters per patient day.

The average oxygen consumption was $41.6( \pm 7.8)$ for the 2019 and 2020 periods, $39.3( \pm 2.7)$ in 2019 , and $43.9( \pm 10.4)$ in 2020 (Table 5).

Table 4: Oxygen Consumption along 2019 to 2020 by month and per patient day with invasive mechanical ventilation.

\begin{tabular}{|l|l|l|l|l|}
\hline Year & Month & $\begin{array}{l}\text { Oxygen Consumption in a } \\
\text { cubic meter }\end{array}$ & $\begin{array}{l}\text { Patient Day with } \\
\text { IMV }\end{array}$ & $\begin{array}{l}\text { Oxygen Consumption per } \\
\text { Patient Day with IMV }\end{array}$ \\
\hline 2019 & 76.924 & 2.045 & 37,6 \\
\hline & January & 73.428 & 1.706 & 43,0 \\
\hline & February & 69.314 & 1.658 & 41,8 \\
\hline
\end{tabular}




\begin{tabular}{|l|l|l|l|l|}
\hline & April & 69.726 & 1.935 & 36,0 \\
\hline & May & 80.010 & 2.036 & 39,3 \\
\hline & June & 70.343 & 1.764 & 39,9 \\
\hline & July & 67.874 & 1.914 & 35,5 \\
\hline & August & 79.392 & 2.003 & 39,6 \\
\hline & September & 66.949 & 1.838 & 36,4 \\
\hline & October & 75.793 & 1.760 & 43,1 \\
\hline & November & 65.715 & 1.574 & 41,8 \\
\hline & December & 75.382 & 1.993 & 37,8 \\
\hline & January & 86.590 & 2.114 & 41,0 \\
\hline & February & 72.191 & 1.821 & 39,6 \\
\hline & March & 90.292 & 2.083 & 43,3 \\
\hline & April & 123.301 & 3.962 & 31,1 \\
\hline & May & 205.441 & 6.738 & 30,5 \\
\hline & June & 240.107 & 7.202 & 33,3 \\
\hline & July & 169.121 & 4.923 & 34,4 \\
\hline & August & 159.667 & 3.001 & 53,2 \\
\hline & September & 131.975 & 2.515 & 52,5 \\
\hline & October & 111.619 & 2.111 & 52,9 \\
\hline & November & 117.389 & 2.105 & 55,8 \\
\hline & December & 142.604 & 2.413 & 59,1 \\
\hline
\end{tabular}

IMV = invasive mechanical ventilation

Table 5: Oxygen Consumption per Patient Day with invasive mechanical ventilation per periods

\begin{tabular}{|l|l|l|l|}
\hline Year & $\mathbf{2 0 1 9}$ and 2020 & $\mathbf{2 0 1 9}$ & $\mathbf{2 0 2 0}$ \\
\hline Mean & 41,6 & 39,3 & 43,9 \\
\hline SD & 7,8 & 2,7 & 10,4 \\
\hline
\end{tabular}

\section{Discussion and Analysis}

The variable with the greatest comparison for resource consumption in the hospital is the patient day. A patient day is a unit of measure that represents the care provided to an inpatient during a hospital day ${ }^{[8]}$.

It is a widely used measure in the area of hospital management based on the construction of other indicators to assess productivity in hospitals ${ }^{[9]}$, or for team sizing ${ }^{[10]}$.

This way, when the indicators are simple to obtain and easy to understand, it helps managers in the art of hospital administration, from its planning to its execution ${ }^{[11]}$.

Having a strong correlation between oxygen consumption in cubic meters and patient day with invasive mechanical ventilation, the average value of 41.6 cubic meters of consumption per patient day with invasive mechanical ventilation opens away in hospital management of medicinal gases, instead of the common Vendor Managed Inventory Supply Chain System model ${ }^{[12]}$.

With this average value found, it can be estimated, for example, in a field hospital with 1,000 beds for COVID-19, a tank of 50 to 60 thousand cubic meters per day is needed. As the lack of oxygen in a crisis like COVID-19 can mean loss of life, contingency measures such as one or two reserve tanks of the same size can be planned.

Therefore, the importance of this indicator of oxygen consumption per patient day with invasive mechanical ventilation.

\section{Limitations}

This study is based on a single-center experience and results may not be widely generalizable.

The 2-year study period is short and it is not possible to state the result of the long-term average, being necessary the elaboration of further studies and future research.

\section{Conclusions}

There is a strong correlation between oxygen consumption in cubic meters and patient days with invasive mechanical ventilation at the Central Institute of HCFMUSP.

The average values of consumption per patient day found can help in planning oxygen management in hospitals.

\section{Abbreviations}

EMR: Electronic Medical Record

HCFMUSP: Hospital das Clínicas of the University of São Paulo School of Medicine

IMV: Invasive Mechanical Ventilation

RIMV: Rate of Invasive Mechanical Ventilation

RNA: Ribonucleic Acid

SD: Standard Deviation

WHO: World Health Organization

\section{Declarations}

\section{Ethics approval and consent to participate}

This is a study about management and process improvement, there was no need to go through the ethics and research committee evaluation.

\section{Conflicts of Interest}

The authors declare that there is no conflict of interest regarding the publication of this paper.

\section{Authors' contributions}


Kaio Jia Bin*\#, ORCID 0000-0002-3767-6288:

Conceptualization, Data Curation, Formal Analysis, Investigation, Methodology, Project Administration, Resources, Software, Supervision, Validation, Visualization, Writing - Original Draft, Review \& Editing.

Luana Alcantara Machado*, ORCID 0000-0003-2367-8829:

Conceptualization, Data Curation, Formal Analysis, Investigation, Methodology, Project Administration, Resources, Software, Visualization, Writing - Original Draft, Review.

Nivaldo Fracacio Junior*, ORCID 0000-0003-0188-4031:

Conceptualization, Data Curation, Formal Analysis, Investigation, Methodology, Project Administration, Resources, Software, Visualization, Writing - Original Draft, Review.

Francis Mironescu Tomazini,

ORCID 0000-0003-4862-2020: data curation, formal analysis, writing, review.

Paula Cristina Souto de Camargo,

ORCID 0000-0001-6094-0895, data curation, formal analysis, project administration, review.

Rosemeire Keiko Hangai,

ORCID 0000-0001-6645-1443, data curation, formal analysis, project administration, review.

Marcelo Camarotto,

ORCID 0000-0002-3568-708X: project administration, resources, visualization, review.

Clarice Tanaka,

ORCID 0000-0003-3900-5944: resources, visualization, review.

Antonio José Rodrigues Pereira,

ORCID 0000-0002-8287-323X: project administration, resources, visualization, review.

\section{References}

[1] WHO. WHO Director-General's opening remarks at the media briefing on COVID-19 - 11 March 2020 Available from: https://www.who.int/directorgeneral/speeches/detail/who-director-general-s-openingremarks-at-the-media-briefing-on-covid-19---11-march2020. Acess at 2021.Jun.

[2] Gagliano A, Villani PG, Co' FM, Manelli A, Paglia S, Bisagni PAG, et al. COVID-19 Epidemic in the Middle Province of Northern Italy: Impact, Logistics, and Strategy in the First Line Hospital. Disaster med. public health prep. 2020;14(3):372-6.

[3] Melesse DY, Chekol WB. The management of patients with coronavirus disease 2019 in intensive care unit (ICU) in low income countries: A review article. Clin Nutr Open Sci. 2021;37:60-72.

[4] Kluge S, Janssens U, Welte T, Weber-Carstens S, Marx G, Karagiannidis C. German recommendations for critically ill patients with COVID-19. Med Klin Intensivmed Notfmed. 2020;115(Suppl 3):111-4.

[5] OPAS OP-AdS. Emergência de oxigênio devido à COVID-19 afeta mais de meio milhão de pessoas em países de baixa e média renda todos os dias Organização Pan-Americana da Saúde: Organização Pan-Americana da Saúde; 2021 Available from: https://www.paho.org/pt/noticias/25-2-2021-emergenciaoxigenio-devido-covid-19-afeta-mais-meio-milhaopessoas-em-paises. Acess at 2021.Jun.

[6] Lavor Ad. Amazônia sem respirar: falta de oxigênio causa mortes e revela colapso em Manaus. 2021. Available from: https://www.arca.fiocruz.br/handle/icict/46768. Acess at 2021.Jun.

[7] Uchoa P. Para além de Manaus, pandemia provoca crise do oxigênio em três continentes. BBC News Brasil. 2021. Available from: https://www.bbc.com/portuguese/internacional55856813. Acess at 2021.Jun.

[8] Brasil. Ministerio da Saude. Secretaria de Assistencia a Saude. Departamento de Sistemas e Redes A. Padronização da nomenclatura do censo hospitalar: Brasil. Ministerio da Saude; 2002. Available from: https://bvsms.saude.gov.br/bvs/publicacoes/padronizacao _censo.pdf. Acess at 2021.Jun.

[9] Bittar OJNV. Produtividade em hospitais de acordo com alguns indicadores hospitalares. Rev. Saúde Pública. 1996;30(1):53-60.

[10] Min A, Scott LD. Evaluating nursing hours per patient day as a nurse staffing measure. J Nurs Manag. 2016;24(4):439-48.

[11] Lima-Gonçalves E, Aché CA. O hospital-empresa: do planejamento à conquista do mercado. Rev. adm. empres. 1999;39(1):84-97.

[12] Pereira SEH. Utilização da prática de VMI no abastecimento de oxigênio em um hospital público. 2012. Available from: http://iepapp.unimep.br/biblioteca_digital/pdfs/docs/1110 2013_151209_suelen.pdf. Acess at 2021.Jun.

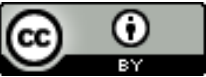

Open Access This article is licensed under a Creative Commons Attribution 4.0 International License, which permits use, sharing, adaptation, distribution and reproduction in any medium or format, as long as you give appropriate credit to the original author(s) and the source, provide a link to the Creative Commons license, and indicate if changes were made. The images or other third party material in this article are included in the article's Creative Commons license, unless indicated otherwise in a credit line to the material. If material is not included in the article's Creative Commons license and your intended use is not permitted by statutory regulation or exceeds the permitted use, you will need to obtain permission directly from the copyright holder. To view a copy of this license, visit https://creativecommons.org/licenses/by/4.0/.

(C) The Author(s) 2021 